\title{
Cardiothoracic Surgery League from University of São Paulo Medical School: twelve years in medical education experience
}

\author{
Doze anos de experiência em Educação Médica da Liga de Cirurgia Cardiotorácica da Universidade \\ de São Paulo
}

Flávio Guimarães FERNANDES ${ }^{1}$, Lucas de Oliveira Serra HORTÊNCIO ${ }^{1}$, Fernando do Valle UNTERPERTINGER ${ }^{1}$, Daniel Reis WAISBERG ${ }^{1}$, Paulo Manuel PÊGO-FERNANDES ${ }^{2}$, Fabio Biscegli JATENE ${ }^{3}$

\section{Resumo}

Introdução: Ligas acadêmicas são entidades pertencentes a faculdades de Medicina e seus hospitais. Compartilham os objetivos: pesquisa, ensino e assistência à saúde. Há doze anos, fundou-se a Liga de Cirurgia Cardiotorácica (LCCT) pela Faculdade de Medicina da USP, com o objetivo de fornecer aos estudantes de Medicina a oportunidade de ter conhecimento mais profundo em Cirurgia Cardiovascular e para participar de iniciação científica nesse campo.

Objetivo: Avaliar a experiência adquirida nos 12 anos de existência da LCCT. Métodos: Membros atuais e antigos da LCCT responderam a um formulário entregue pessoalmente ou por e-mail, fornecendo opinião geral (e suas razões) sobre atividades da LCCT e escolha de especialidades médicas. $O$ total de produção científica da LCCT foi também contabilizado.

Resultados: A maioria dos atuais estudantes 51/65 (78,5\%) e ex-membros $94 / 121(77,7 \%)$ respondeu ao formulário. O interesse em Cirurgia Cardiovascular foi o motivo mais apontado para ingressar na LCCT, representrando 44/161 (27,3\%). A maioria dos estudantes - 32/51 (62,7\%) - relatou que suas perspectivas iniciais foram parcialmente preenchidas. Quase todos os membros recomendariam a um colega participar da liga 50/51 (98\%) e 25/51 (49\%) deles participaram de uma iniciação científica vinculada à LCCT. No total, 47 trabalhos científicos com alunos da LCCT como autores ou coautores foram publicados. Dentre os exmembros que optaram por uma carreira cirúrgica, 7/52 $(13,4 \%)$ deles escolheram Cirurgia Torácica ou Cardiovascular.

Conclusão: LCCT cumpriu seus objetivos, os alunos reconheceram a colaboração da LCCT na sua formação médica, além de ter se mostrado um bom meio de realizar iniciação científica.

Descritores: Educação de graduação em Medicina. Cirurgia torácica. Educação médica.
1. Graduando da Faculdade de Medicina na Universidade de São Paulo.

2. Professor Associado do Departamento de Cardiopneumologia da FMUSP; Médico assistente da Disciplina de Cirurgia Torácica da FMUSP.

3. Professor Titular da Disciplina de Cirurgia Torácica da FMUSP.
Endereço para correspondência:

Flávio Guimarães Fernandes

Av.Diógenes Ribeiro de Lima 1376 - São Paulo, SP, Brasil - CEP: 05458-001

E-mail: flavichio@hotmail.com 


\begin{abstract}
Introduction: Academic Leagues (Academic Interest Group) are entities that belong to medical schools and their hospitals. Their goals are research, medical education and health care. The cardiothoracic Surgery League (Liga de Cirurgia Cardiotorácica - LCCT), University of São Paulo Medical School, was founded 12 years ago, aimed at providing undergraduate medical students an opportunity to expand knowledge in cardiothoracic surgery and to take part in scientific studies in the field.

Objective: To evaluate the experience gained through LCCT implementation.

Methods: Current students and former members of LCCT were submitted to a specific evaluation form, delivered personally or by email, which provided data on the general opinion regarding LCCT's activities, the reasons for answers provided and choice of medical specialties. Furthermore, LCCT's total scientific production was evaluated. Results: Most undergraduate medical students 51/65 (78.5\%) and
\end{abstract}

\section{INTRODUCTION}

Academic leagues are entities that belong to medical schools and their hospitals. They share the same objectives as their academic centers: research, medical education and health care. League members include students and related professionals from their respective health areas. Their board of directors includes students who are supported by medical professionals, especially physicians from the respective league's service.

Since long, there has been a discussion whether academic leagues have a positive impact on students training. Despite this controversy, the number of academic leagues has been dramatically increasing throughout the country. In addition, there are league associations, such as the Brazilian Society of Cardiology Leagues (Sociedade Brasileira de Ligas de Cardiologia - SBLC), which includes almost 80 leagues and organizes symposia and conferences, indicating the organizational level these entities can achieve [1].

Besides, scientific studies show that academic leagues tend to follow the same model, based on the objectives of their academic centers described above [2,3]. This fact is interesting because, since the first league in Brazil, almost all leagues have followed this pattern without deep changes, indicating whether it is a good undergraduate medical education model.

The first league to be registered in Brazil was the Syphilis Combat League, founded in the 20ies and still former members $94 / 121(77.7 \%)$ completed the form. The interest in Cardiothoracic Surgery was the most common reason for joining LCCT 44/161 (27.3\%). Most students $32 / 51(62.7 \%)$ - reported their initial expectations were partially met. Almost every member would recommend a fellow medical student to join LCCT 50/51 (98\%) and 25/51 $(49 \%)$ of them participated in a scientific project linked to LCCT. In total, 47 scientific papers were published having LCCT's medical students as authors or co-authors during the existence of the league. Of the former members who chose a surgical career, $7 / 52(13.4 \%)$ chose thoracic or cardiovascular surgery.

Conclusion: LCCT has met its goals, since most current and former members recognized its role in their medical training, besides it is a good way to produce scientific initiation.

Descriptors: Education, medical, undergraduate. Thoracic surgery. Education, medical. operating at the University of São Paulo Medical School (FMUSP). This league had cared for 25,536 patients after its first 20 years of existence [4]. No further data were found, however, one can imagine the number of people that have been seen to the present data.

Some academic leagues, such as the Pain League, FMUSP, the Bahia League of Plastic Surgery, Bahia Federal University and the League for the Prevention and Control of Oral Cavity Cancer, FMUSP have published the balance of their activities showing their efficacy and positive results [5-7]. The Cardiothoracic Surgery League - LCCT, which had been operating for 12 years in 2009, has also proposed to gather data on the experiences obtained by its students, former members and professors.

LCCT belongs to FMUSP and was founded on December 10,1996 . Its objectives are to introduce cardiovascular and thoracic surgery to students at São Paulo State medical schools and promote different scientific activities.

The initiative to create a league was triggered by an elective course taught at FMUSP on the same theme, the increasing number of students attending the course and its good reputation among students. The idea of an elective course and a league are closely related in terms of academic training, however, even though the former includes some practical activities, the relationship among student, course and career does not reach the same levels as in the activities of the leagues.

The LCCT is therefore aimed at complementing undergraduate medical training and providing students an opportunity to experience medical practice with 
professionals of the area going beyond theoretical perspectives. In addition to knowledge, the league's activities provide an extensive exchange of experiences among its members.

LCCT effective members are undergraduate students from $1^{\text {st }}$ to the $4^{\text {th }}$ year of medical schools in São Paulo State (undergraduate medical programs in Brazil include six years of training). Residents and assistant physicians of the Cardiovascular Surgery and Thoracic Surgery Services, Hospital das Clínicas are LCCT counselors. It is coordinated by Dr. Paulo Manuel Pêgo-Fernandes and supervised by Prof. Dr. Fabio Biscegli Jatene. Prof. Dr. Adib Domingos Jatene it the league's president of honor.

LCCT is a non-profit organization ruled according to its by-laws. It is administered by a board of directors including three members (President Director, Secretary Director and Treasurer Director) which is elected according to the rules established by the by-laws. One hundred and sixty-one students have participated in the league, of which $10 \%$ were from other universities. A course with lectures is held on a yearly basis. There are eight 45 -minute lectures, totaling over 6 hours. At the end of the course a test is given including questions on the themes discussed in the lectures.

The activities promoted by LCCT members are:

1. Lectures

Theoretical classes are given every other week on:

- $\quad$ Topics of interest in cardiothoracic surgery;

- $\quad$ Medical literature review and analysis;

- Scientific papers: writing, structure and types of publications.

\section{Scientific Meetings}

Held every other week to follow-up scientific papers carried out by the league's members and distribution of projects among those who manifest their interest.

\section{Practices:}

- Desiccation in the City's Death Verification Service;

- $\quad$ Participation in experimental studies;

- Visits to the surgical center, postoperative recovery unit and Thoracic Surgery ward.

The objective of the present study is to assess the activities of the league during its 12 years of experience by means of the following indices:

- $\quad$ Students appraisal of the leagues activities;

- Evaluate if the league supports them in their medical training;

- Evaluate their opinion on the league's scientific initiation activities;

- $\quad$ Number of scientific papers produced during this period;
- $\quad$ Evaluate the influence of the league on the choice of medical specialty of former LCCT members.

\section{METHODS}

Students who joined the LCCT were divided into two groups. The first included undergraduate students, i.e. those who were in the last year of medical school or less in the second semester of 2009 and those who had graduated from medical school within the last two years, most of them in the $2^{\text {nd }}$ year of Medical Residency. The second group included those who had graduated more than 2 years before.

The first group was submitted to anonymous questionnaires. The questionnaires were personally handed to them or were sent by e-mail. The questions tried to find out the reasons which led them to participate in the League and analyze their experience, including the participation in research projects and their opinion on the remaining activities. The questionnaire also analyzed the influence of the League on respondents' graduation and professional expectations.

As to the second group, we chose to contact them by telephone or e-mail and only find out the medical specialty they had chosen, due to the difficulty to deliver the questionnaire and because respondents might be subject to variables leading to confusion due to the long period they had been away from the academic environment.

To gather data on the scientific projects carried out by students during their participation in the League, the following public database were used: PubMed, LILACS and Sistema Lattes. To enable proper data retrieval, the references of students, medical counselors participating in the League and the correct chronological period were crossed.

Information was entered and formed the database upon which this study is based. Therefore, it is a descriptive study based on the opinion of the current students and former members of LCCT.

\section{RESULTS}

Among those who were chosen to answer the questionnaire (first group), a compliance rate of 78.5\% (51/ 65 ) was obtained. Among those who were selected for the specialty survey (second group), a compliance rate of $77.7 \%$ (94/121) was obtained. The responses to the questionnaire might be seen in Tables 1 to 4 (those who answered questions 1 to 4 could take more than one answer, reason why the denominator is different in the tables).

When asked about the reasons which led them to participate in LCCT, the most frequent reason was the interest in Cardiothoracic Surgery (Table 1). 
When asked if their initial expectation was met, the most frequent answer was that their objectives were only partially met (32/51; 62.7\%). About 33.3\% (17/51) answered their expectations were totally met, whereas $4 \%(2 / 51)$ gave the opposite answer. The reasons for not meeting their initial objectives are shown in Table 2. The three most frequent reasons were the limited participation in surgeries, lack of personal time and not enough activities at the Death Verification Service.

As to the reasons leading members and former members to be pleased about their participation in the League, results are shown in Table 3. The main reasons were the lectures given at LCCT, followed by visits to the postoperative recovery unit and to the Heart Institute Patient Ward. When asked if they would indicate the League to other students, the large majority of members and former members gave a positive answer (50/51; 98\%).

When asked if the theoretical content usually given in the cardiothoracic surgery program is enough for the training of a primary care physician, most students gave an affirmative answer (22/51; 43.1\%), whereas 39.2\% (20/51) gave a negative answer. About 17.6\% (9/51) did not know the answer to this question.

Table 1. Reasons given for interest in joining LCCT.

\begin{tabular}{lcc}
\hline Reasons & N & $\%$ \\
\hline Interest in Cardiothoracic surgery & 44 & 27.3 \\
Improve current knowledge on Cardiothoracic surgery & 25 & 15.5 \\
Interest in scientific projects related to Cardiothoracic surgery & 24 & 14.9 \\
Interest in practicing surgical technique at SVOC & 26 & 16.1 \\
Learn about the routine of a cardiothoracic surgeon & 19 & 11.8 \\
Participate in surgical procedures & 23 & 14.3 \\
TOTAL & 161 & 100.0 \\
\hline SVOC - City's Death Verification Service &
\end{tabular}

Table 2. Reasons given for not meeting their initial expectations when joining LCCT.

\begin{tabular}{lcc}
\hline Reasons & $\mathrm{N}$ & $\%$ \\
\hline Lack of opportunities to participate in a scientific project & 4 & 4.8 \\
Limited number of lectures & 1 & 1.2 \\
Limited number of activities at SVOC & 16 & 19.0 \\
Limited number of visits to intensive care units (ICU) or wards & 10 & 11.9 \\
Limited number of case discussions & 10 & 11.9 \\
Lack of opportunities to take part in surgical procedures & 20 & 23.8 \\
Personal limitation: lack of time & 15 & 17.9 \\
Lack of training in a specific procedure & 8 & 9.5 \\
TOTAL & 84 & 100.0 \\
\hline
\end{tabular}

As to the participation in the scientific initiation project, $49 \%$ (25/51) of the respondents gave an affirmative answer. The reasons indicated for those who gave a negative answer to this question are listed in Table 4. The results obtained for the number of papers with the participation of students are shown in Figures 1, 2, 3 and 4. A total of 47 scientific papers were published in journals, 53 abstracts were published in conference annals and 58 presentations were given in conferences. LCCT currently has 13 ongoing scientific initiation projects.

As to the specialization area of students in the last year of medical school and former students, 55.3\% (52/94) chose surgical areas, whereas $44.7 \%$ (42/94) chose non-surgical areas. Of these, 9.5\% (4/42) preferred Cardiology and 7.1\% (3/42) Pneumology. Of those who chose surgery, 9.6\% (5/ 52) specialized in Thoracic surgery and $3.8 \%(2 / 52)$ in Cardiovascular surgery. Of students in the last year of medical school, 69.2\% (9/14) stated LCCT had an influence on the choice of their specialization. For methodological purposes, we have classified medical specialties into surgical and non-surgical, according to CREMESP's (Regional Council of Medicine of the State of São Paulo) definitions [8].

Table 3 Reasons given reaching their goals during their participation in LCCT.

\begin{tabular}{lcc}
\hline Reasons & $\mathrm{N}$ & $\%$ \\
\hline Participation in scientific projects & 13 & 15.7 \\
Lectures & 20 & 24.1 \\
Visits to ICUs or wards & 16 & 19.3 \\
Activities performed at SVOC & 15 & 18.1 \\
General experience and knowledge gained through LCCT & 15 & 18.1 \\
Participation in Medical Conferences & 4 & 4.8 \\
TOTAL & 83 & 100.0 \\
\hline
\end{tabular}

Table 4. Reasons given not to participate in a scientific project linked to LCCT.

\begin{tabular}{lcc}
\hline Reasons & $\mathrm{N}$ & $\%$ \\
\hline Lack of personal interest & 6 & 14.6 \\
Lack of opportunities in LCCT & 6 & 14.6 \\
Personal limitation: lack of time & 14 & 34.1 \\
Scientific meetings at inconvenient times & 9 & 22.0 \\
Already involved in another scientific project & 6 & 14.6 \\
TOTAL & $41^{*}$ & 100.0 \\
\hline
\end{tabular}

*Only 25 students answered this question 


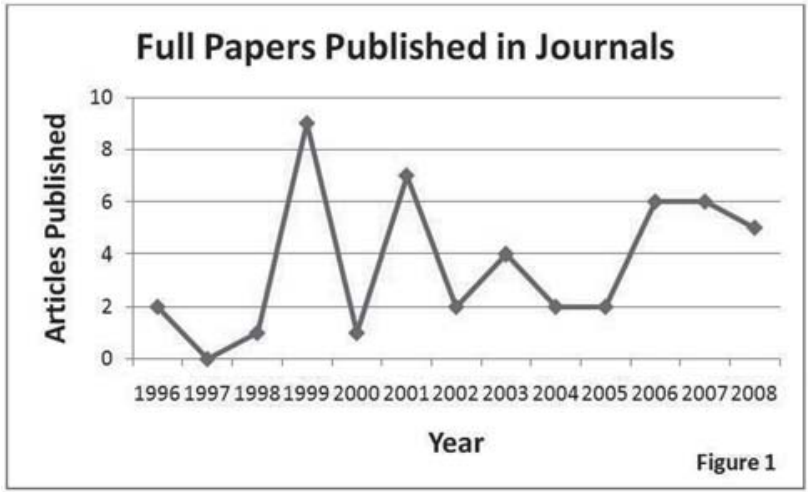

Fig. 1 - Total of scientific papers published having LCCT's undergraduate medical students as main authors or co-authors

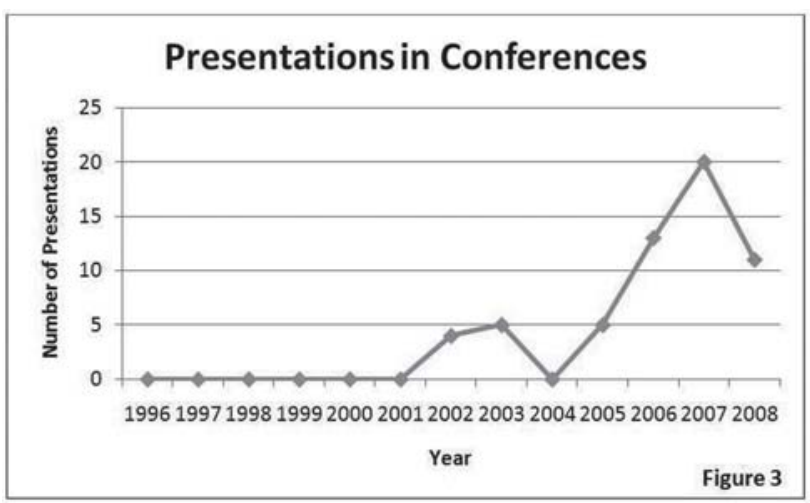

Fig. 3 - Total of studies presented in medical conferences with LCCT's undergraduate medical students as main authors or coauthors

\section{DISCUSSION}

One of the objectives of the present study is to obtain a critical self-evaluation of LCCT. The authors believe that the league provided students an effective opportunity to obtain experience, since $33.3 \%$ of them had their expectations totally met during their participation in the league, whereas $64.7 \%$ had their expectations partially met.

Most students said the classes given and the knowledge and experience obtained were the main reason for their satisfaction. The result was surprising, since we believed that due to the large amount of theoretical classes in their regular program, students would be less interested in theoretical activities.

Limited participation in surgical procedures and lack of personal time were the most frequent reasons for partially meeting their objectives. We understand that because LCCT

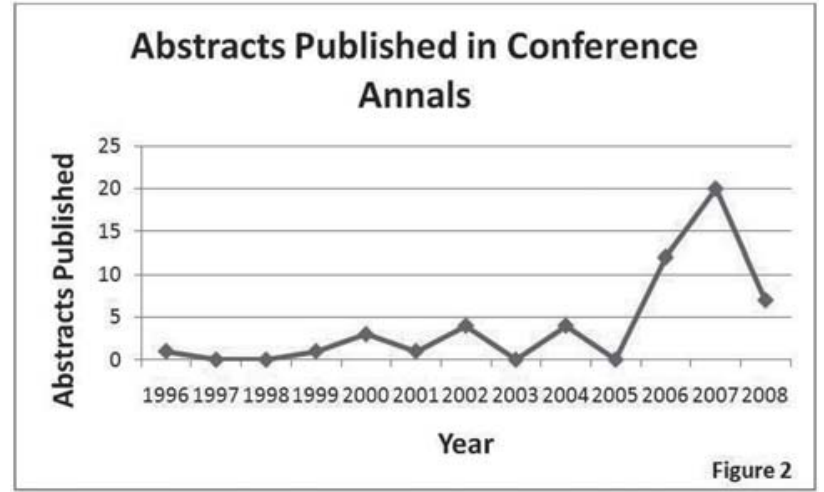

Fig. 2 - Total of abstracts published in annals of medical conferences having LCCT's undergraduate medical students as main authors or co-authors

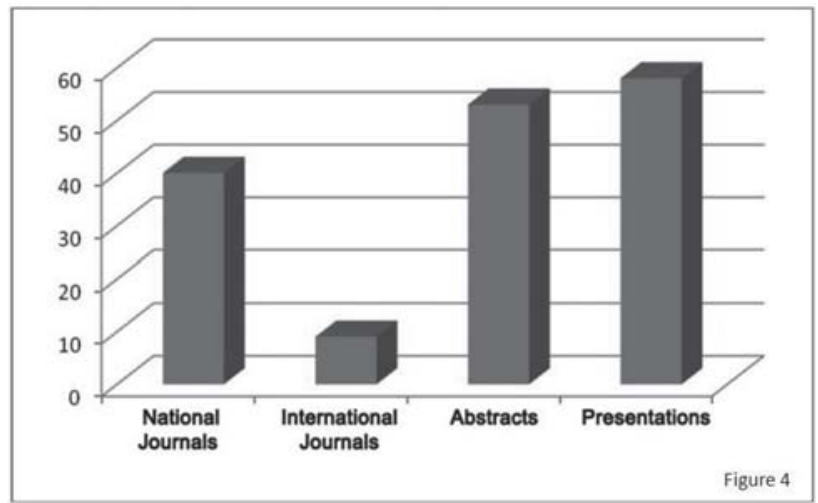

Fig. 4 - LCCT's overall scientific production

is a surgical league, the participation in surgical procedures and visits to surgical centers are one of the greatest expectations of participants. However, we have to face ethical and operational obstacles, since the participation of students in the first 4 years of medical school and therefore with limited surgical experience may interfere with the optimal performance of the surgical act, thus interfering with the best interests of the patient. This is especially true in our area, where surgeries often have great risks.

The number of hours of the Medical School program is in itself extensive and takes up a major part of students' time. In addition, there are several extracurricular activities, ranging from participation in sports and different academic activities. It is the role of the student to define priorities and it is not surprising that the lack of time represents a major limitation when trying to reach their goals.

Scientific initiation is one of the highlights among the activities a student may participate in. Even if the student 
does not wish to pursue an academic career, participation in research projects should be encouraged, since it provides experience and the ability to critically read scientific papers and specialized literature, which is essential for their professional life, due to the constant need to update.

Literature review shows that in general, less than one quarter of medical students participate in research projects during their training $[9,10]$. Our study indicated that $49 \%$ of respondents participated in scientific initiation projects linked to the League. Different factors may contribute to this significant difference. Among them, the participation of students from other institutions adds the transfer from one place to another as one more obstacle for the participation in projects. However, this result may also indicate that the League has positively influenced its members to participate in research activities. The main reason for not participating in scientific projects was lack of time.

The reasons for the limited availability of medical students have been previously discussed. Many of them considered the times of LCCTs scientific meetings as a disencouraging factor. This has always been a concern for the league's board of directors. The meeting is held every other week on Thursdays at $7 \mathrm{am}$. Several other times have been attempted, but students' attendance did not improve. We believe that continuous communication may lead to a consensus that best suits the needs of students and it is something that must be reevaluated.

As a result of the significant participation of students in research projects throughout its 12 years of activity, the League has a total of 47 full papers published in specialized journals. The variation in the number of publications throughout this period might be explained by the long time required to conclude a research project and by the variability in the offer of research projects. The number of publications has increased over the years, indicating a progressive increase in the number of papers published in connection with LCCT.

We have noted that the participation of LCCT students in conferences has significantly increased over the last few years. This is relevant, since students gain experience by participating in conferences and giving presentations in conference studies, which is important for an optimal professional training.

In the last few years, the amount of discoveries in the medical field has increased dramatically. However, there has not been a significant increase in the duration of the basic course. Therefore, it is impossible to offer students enough exposure to all medical specialties during their training.

Academic leagues may be a good alternative to this scenario, since they offer students the opportunity to directly interact with the specialties they like best and they also facilitate the participation in scientific initiation projects, medical practice and contact with patients. When this takes place, the league meets the objectives of the large medical education centers: medical education, research and health care [3].

Most of the respondents believe that the content of cardiothoracic surgery program in undergraduate medical schools is enough for the training of a primary care physician. On the other hand, almost all of these students would recommend the League to other students. At a first sight, these data may seem conflicting, since if the training program is good enough, it would not be necessary to participate in an extracurricular activity on the same theme. However, the extensive referral for participation in LCCT clearly shows that the final objective of this institution is not to complement an inadequate theoretical program, but provide students an opportunity to be in closer contact with a medical specialty.

The choice of a specialty is not an easy task for students in the last year of medical school. Although the objective of our academic leagues is not to provide early specialization, they are a good alternative to enable contact with the routine of a specialist, providing students subsidies to help them make choices regarding their future professional career. Scientific studies try to show the reasons why students choose their specialties [11,12]. The study reveals complexity of this choice, just the fact that students have participated in an academic league does not mean that they have accomplished their professional career.

Literature data show that the early contact with a specialty might help them make this decision [12]. Our data corroborate this, since $69.2 \%$ of those who have chosen their specialty have stated the experience obtained in LCCT has influenced this decision.

The statement above may be confirmed by the data gathered on the specialties chosen by former students. Since the league is surgical, $55.3 \%$ of the students chose this area, which is a significant number if we consider that openings in this area correspond to only $18.9 \%$ of the overall number of positions available for residency at Hospital das Clínicas, FMUSP. Of the students who chose surgical residency, $13.4 \%$ specialized in cardiovascular or thoracic surgery. Even in the clinical area, $16.6 \%$ specialized in Pneumology or Cardiology. It's important to remember that the present study is not aimed at analyzing the reasons leading to students career choices.

\section{CONCLUSION}

Students approved the activities promoted by LCCT and most of them would indicate it to other students. They believe that the League supports their medical training, even though the content of their training program is enough 
for the career. LCCT proved to be an effective method for scientific initiation from the time of its foundation, with the publication of 47 papers in specialized journals. As to the choice of medical specialty, most of the former participants of the league followed a surgical career, as expected, however there was no significant trend towards the cardiac or thoracic specialty.

\section{REFERENCES}

1. Guimarães-Fernandes F. Roteiro de organização de ligas acadêmicas. Disponível no sítio: http://www.sbccv.org.br/ residentes/roteiro_liga.asp.

2. Neves FBCS, Vieira PS, Cravo EA, Dias M, Guimarães HP, Bitencourt $\mathrm{A}$, et al. Inquérito nacional sobre as ligas acadêmicas de Medicina Intensiva. Rev Bras Ter Intensiva. 2008;20(1):43-8.

3. Gonçalves RJ, Ferreira EAL, Gonçalves GG, Lima MCP, Ramos-Cerqueira ATA, Kerr-Correa F, et. al. Quem “liga” para o psiquismo na escola médica? A experiência da Liga de Saúde Mental da FMB - Unesp. Rev Bras Educ Med. 2009;33(2):298-306.

4. Burjato Júnior D. História da Liga de Combate à Sífilis e a evolução da sífilis na cidade de São Paulo (1920-1995) [Dissertação de Mestrado]. São Paulo: Faculdade de Medicina. Universidade de São Paulo; 1999.
5. Pimenta CAM, Teixeira MJ, Simões P, Simões C, Cruz DALM, Okada M. Liga de Dor: uma experiência de ensino. Rev Hosp Clin Fac Med Univ São Paulo. 1998;53(4):214-21.

6. Monteiro LLF, Cunha MS, De Oliveira WL, Bandeira NG, Menezes JV. Ligas acadêmicas: o que há de positivo? Experiência de implantação da Liga Baiana de Cirurgia Plástica. Rev Bras Cir Plast. 2008;23(3):158-61.

7. Vanderlei FAB, Pereira FC, Barreto RL, Matsunaga P, Durazzo MD, Tavares MR, et al. Três anos de atividades da Liga de Prevenção e Controle de Câncer da Cavidade Oral. Rev Med (São Paulo). 1998;77(3):179-82.

8. Especialidades Médicas no Estado de São Paulo - Cremesp. Disponível em: http://www.cremesp.org.br/library/modulos/ centro_de_dados/arquivos/especialidades.pdf

9. Carneiro AE. Amostragem sobre a situação da Pesquisa Científica na Universidade Brasileira. Pesqui Med (Porto Alegre). 1985;19(2):113-5.

10. Sarinho SW, Kovacs MH, Santos FGPL, Beltrão RCIC, Santiago RRS, Alencar SA. Perfil da produção de iniciação científica dos alunos de medicina na Universidade de Pernambuco. An Fac Med Univ Fed Pernamb. 2003;48(2):106-10.

11. Neves FBCS, Vieira PSPG, Cravo EA, Portugal TS, Almeida MF, Brasil ISPS, et al. Motivos relacionados à escolha da medicina intensiva como especialidade por médicos residentes. Rev Bras Ter Intensiva. 2009;21(2):135-40.

12. Gott VL, Patel ND, Yang SC. Attracting outstanding students (premedical and medical) to a career in Cardiothoracic Surgery. Ann Thorac Surg. 2006;82(1):1-3. 